\title{
Genetic Variability Studies for Yield and it's Attributing Traits in Potato (Solanum tuberosum L.)
}

\author{
Lopamudra Singha* and Zafar Ullah
}

Department of Plant Breeding and Genetics, Assam Agricultural University, Jorhat -13, India

*Corresponding author

\section{A B S T R A C T}

\begin{tabular}{|l|}
\hline Ke y w o r d s \\
Potato, Genetic \\
Variability, GCV, \\
PCV, Heritability, \\
Genetic Advance \\
\hline Article Info \\
\hline $\begin{array}{l}\text { Accepted: } \\
\text { 15 January } 2020 \\
\text { Available Online: } \\
\text { 10 February } 2020\end{array}$ \\
\hline
\end{tabular}

The present investigation was undertaken to estimate genetic variability, heritability, and genetic advance for important yield component characters among thirty eight genotypes of potato in a randomized block design with two replications during two Rabi seasons. The analysis of genetic variance revealed that there was significant genetic variability in the experimental materials. Among all the genotypes studied, genotype CP 1994 showed highest tuber yield per plant, marketable tuber yield per plant and number of branches per plant and found suitable to further crop improvement programme. Among the characters studied, high PCV and GCV were observed for characters like total tuber yield (42.57 and 41.67 respectively), Leaf Area Index (41.39 and 31.62 respectively) and marketable tuber yield (40.83 and 33.89 respectively) indicating high variability available in the genotypes for these characters for further improvement. A high heritability $(>60 \%)$ coupled with high genetic advance was found for Leaf Area Index, marketable tuber yield and total tuber yield which suggested that there may be presence of additive gene action and selection will be rewarding for improvement of such traits.

\section{Introduction}

Potato is the 4th important food crop in the world after wheat, rice and maize. According to Visser et al., (2009), by 2020 more than two billion people of Asia, Africa and Latin America will be depending on root and tuber crops for food, feed or income. It is known as 'King of Vegetables'. Potato has very good nutritional importance and it can produce more energy and protein per unit area per unit time than most other major food crops and contains substantial amounts of minerals. Parameters of genotypic and phenotypic coefficients of variation (GCV and PCV) are useful in detecting the amount of variability present in the available genotypes. Heritability and genetic advance help in determining the influence of environment expression of the characters and the extent to which improvement is possible after selection (Robinson et al., 1949). The total variability can be partitioned into heritable and nonheritable components with the help of genetic parameters like genotypic and phenotypic coefficients of variation, heritability and genetic advance. High heritability alone is not enough to make efficient selection in segregating generation, unless the information is accompanied for substantial amount of 
genetic advance (Johnson et al., 1955). In India, such studies in potato have been made either under sub-tropical plains or temperate hill conditions with different sets of genotypes (Gopal, 1999).

When the variability in a population is largely of genetic nature with least environmental effect, the probability of isolating superior genotypes is high. Since information on potato progeny is not available in our country, the results reported in the study are related to select a suitable plant type having high yield with good natural keeping quality (Kanika, 2010).

\section{Materials and Methods}

\section{Plant materials and field experimentation}

The present investigation entitled "Genetic Variability Studies in potato (Solanum tuberosum L.)" was conducted at Instructional-Cum-Research (ICR) farm of Assam Agricultural University, Jorhat during Rabi season 2016-17 and 2017-18. Geographically, it is located at latitute- $26^{\circ} 45^{\prime}$ $\mathrm{N}$, longitue- $94^{\circ} 12^{\prime} \mathrm{E}$, having an elevation of $87 \mathrm{~m}$ above the mean sea level. The topography of the land was uniform. The experiment was laid out in a Randomized Block Design with two replications and plot size of $1 \mathrm{~m} \times 1 \mathrm{~m}$. The experimental material for the present investigation comprised of thirty seven genotypes of potato along with two check varieties (Table 1). These thirty seven genotypes and two check varieties were collected from AICRP on potato, AAU, Jorhat center with a spacing of $50 \mathrm{~cm} \times 20 \mathrm{~cm}$.

The tubers were planted on 15th November 2016. Well rotten Farm Yard Manure (FYM) was mixed in the field @ $20 \mathrm{t}$ ha-1 before ridging along with $\mathrm{N}: \mathrm{P}_{2} \mathrm{O}_{5}: \mathrm{K}_{2} \mathrm{O}$ @ 150:100:100 kg/ha. The height of ridges was kept $15 \mathrm{~cm}$ and there were two ridges in each plot. The entire quantity of phosphorus and potassium was applied at the time of planting in the form of SSP and MOP, respectively. However, nitrogen was applied in each plot in two split doses in the form of Urea at 30 and 45 days after planting. Operation of weeding, earthing up, plant protection and irrigation were performed as per recommendations and when required. Data on yield and yield contributing characters were recorded from five randomly selected plants in each plot.

The same genotypes were raised during 201718 for another season evaluation and tubers were planted on 20th November 2017 with the same design and plot size and similar agronomic practices.

\section{Characters recorded}

Thirty seven genotypes of potato were evaluated for different characters viz., plant height $(\mathrm{PH})$, number of branches per plant(BR), ground coverage (GC), leaf area index (LAI), total number of tubers plant ${ }^{1}$ (TUB), average tuber weight plant $^{-1}$ (ATW), marketable tuber yield plant ${ }^{-1}(\mathrm{MYP})$ total tuber yield plant $^{-1}$ (TYP).

\section{Statistical methods}

Analysis of variance was carried out as per the procedure given by Fisher's method. Genotypic variances $\left(\sigma^{2} \mathrm{~g}\right)$, phenotypic variance $\left(\sigma^{2} p\right)$ and environmental variance $\left(\sigma^{2} \mathrm{e}\right)$ were computed according to Burton and Devane (1953) and Allard (1960).

Genotypic coefficient of variation (GCV) and phenotypic coefficient of variation (PCV) were estimated from these variances in terms of standard deviation as percentage of the grand mean. Expected genetics advance for each character was calculated according to Johanson, Robinson and Comstock (1955). 


\section{Results and Discussion}

Assessment of genetic variability and diversity is very crucial for plant breeding as well as for efficient management and conservation of germplasm resources. Plant germplasm of a crop provides greater genetic variability while furnishing useful traits to enhance the genetic base of that crop for the breeder.

\section{Analysis of variance (ANOVA)}

Parameters of genetic variability work out from pooled analysis of two season data in 2016-17 and 2017-18. The analysis of variance given in Table 2 revealed that the differences due to the genotypes were highly significant for plant height, number of branches per plant, ground coverage, leaf area index, number of tuber per plant, average tuber weight, marketable tuber yield and total tuber yield.

The mean performance of tuber yield and its components for all the thirty eight genotypes are shown in the Table 3 revealed that among the characters plant height, number of branches per plant, ground coverage, leaf area index, average tuber weight, total number of tubers per plant, marketable tuber yield, were the prominent yield contributing characters as evident from their high mean performance in conjuction with high total tuber yield. The present findings were in agreement with the findings of Dayal et al., (1972) for total tuber yield, number of branches; Choudhary and Sharma (1984) for tuber yield, number of tubers per plant; Rana et al., (1996) for average tuber weight; and Roy and Sharma (2000) for plant height and tuber yield; Asefa et al., (2016) for leaf area index, average tuber weight and marketable tuber yield; Mishra et al., (2017) for marketable tuber yield and total tuber yield.

\section{Coefficient of variation}

In present investigation variability parameters such as range, mean, genotypic coefficient of variation, phenotypic coefficient of variation, heritability in broad sense and genetic advance (percent mean) for tuber yield and its components are present in Table 4.High magnitude of phenotypic coefficient of variance and genotypic coefficient of variance (PCV and GCV) was observed for total tuber yield 42.57 and 41.67 respectively followed by marketable tuber yield (41.39 and 31.62 respectively) and leaf area index (40.83 and 33.89 respectively). The lowest PCV and GCV were observed in plant height (23.01 and 15.37 respectively).The high magnitude of PCV (i. e. >35\%) recorded for LAI, average tuber weight, marketable tuber yield and total tuber yield and high GCV recorded for total tuber yield suggests the substantial improvement on potato through selection for these traits. However, the moderate GCV was recorded for the traits ground coverage, LAI, marketable tuber yield and total tuber yield suggest existence of considerable variability in the population. Selection for these traits may also be given the importance. These findings are in accordance with the findings by $\operatorname{Garg}(1988)$ for total tuber yield and average tuber weight, number of tuber plant ${ }^{-1}$; Dixit et al., (1991) for number of branches per plant; and Rasul et al., (1995) for tuber yield per ha for average tuber weight Kumar et al., (2005); for tuber number, plant height by Joseph (2005); whereas, Mishra et al., (2006) recorded high magnitude of PCV and GCV for plant height, tuber yield, leaf area index, Haydar et al., (2009), for plant height, total tuber and tuber yield, Khan et al., (2011) for plant height, average tuber weight, The moderate PCV and GCV were reported by Luthra et al., (2005).

Present study, indicating that total tuber yield, marketable tuber yield and average tuber 
weight, leaf area index, ground coverage, possessed high to moderate value of GCV and PCV suggesting the existence of considerable variability in potato genotypes. Hence, selection for these traits may useful for the improvement of tuber yield.

\section{Heritability and Genetic advance}

Heritability estimates in broad sense were calculated for tuber yield and its components and presented in Table 4. Estimate of heritability was recorded high for the character total tuber yield per plant (95.80). Heritability estimates in broad sense were calculated for tuber yield and its components. These are grouped into high (> 60 per cent) moderate (30 to 60 per cent) and low $(<30$ per cent).

Table.1 Genotypes included in the present study

\begin{tabular}{|l|l|l|l|}
\hline SL. NO. & GENOTYPES & SL. NO. & GENOTYPES \\
\hline $\mathbf{1}$ & CP 1913 & 22 & CP 1962 \\
\hline $\mathbf{2}$ & CP 2012 & 23 & CP 1902 \\
\hline $\mathbf{3}$ & CP 1901 & 24 & CP 1994 \\
\hline $\mathbf{4}$ & CP 1893 & 25 & CP 1997 \\
\hline $\mathbf{5}$ & CP 1918 & 26 & CP 1987 \\
\hline $\mathbf{6}$ & CP 1964 & 27 & CP 1982 \\
\hline $\mathbf{7}$ & CP 2017 & 28 & CP 2048 \\
\hline $\mathbf{8}$ & CP 1909 & 29 & CP 2016 \\
\hline $\mathbf{9}$ & CP 1915 & 30 & CP 1916 \\
\hline $\mathbf{1 0}$ & CP 1936 & 31 & CP 2008 \\
\hline $\mathbf{1 1}$ & CP 1908 & 32 & CP 2015 \\
\hline $\mathbf{1 2}$ & CP 2038 & 33 & CP 1981 \\
\hline $\mathbf{1 3}$ & CP 1933 & 34 & CP 2045 \\
\hline $\mathbf{1 4}$ & CP 2052 & 35 & CP 1914 \\
\hline $\mathbf{1 5}$ & CP 1999 & 36 & CP 1924 \\
\hline $\mathbf{1 6}$ & CP 1911 & 37 & CP 1986 \\
\hline $\mathbf{1 7}$ & CP 2021 & 38 & KufriJyoti \\
\hline $\mathbf{1 8}$ & CP 1998 & 39 & KufriKhyati \\
\hline $\mathbf{1 9}$ & CP 2023 & & \\
\hline $\mathbf{2 0}$ & CP 1931 & & \\
\hline $\mathbf{2 1}$ & CP 2010 & & \\
\hline of all genotypes-AICRP on potato, AAU, Jorhat center & & \\
\hline
\end{tabular}

*Source of all genotypes-AICRP on potato, AAU, Jorhat center 
Table.2 Pooled ANOVA for different characters of 2016-17 and 2017-18

\begin{tabular}{|c|c|c|c|c|c|c|c|}
\hline \multirow[t]{2}{*}{ Characters } & \multicolumn{6}{|c|}{ Mean sum squares } & \multirow[t]{2}{*}{$\mathrm{CV}(\%)$} \\
\hline & $\begin{array}{c}\text { Genotypes } \\
\quad d f-37\end{array}$ & $\begin{array}{c}\text { Replication } \\
d f-1\end{array}$ & $\begin{array}{c}\text { Environments } \\
\quad d f-1\end{array}$ & $\begin{array}{c}\text { Interactions } \\
d f-1\end{array}$ & $\begin{array}{l}\text { Overall Sum } \\
\quad d f-3\end{array}$ & $\begin{array}{c}\text { Error } \\
d f-111\end{array}$ & \\
\hline Plant height & $72.59 * *$ & 0.46 & 406.79 & 43.21 & 150.15 & 17.19 & 17.13 \\
\hline No. of branches per plant & $1.34 * *$ & $6.32 * *$ & 0.16 & 0.80 & 2.43 & 0.66 & 36.69 \\
\hline Ground coverage & $264.54 * *$ & 5.53 & 5532.17 & 15.80 & 1851.16 & 42.98 & 18.19 \\
\hline Leaf area index & $14.82 * *$ & $11.42 * *$ & 29.09 & 0.65 & 13.72 & 1.50 & 22.76 \\
\hline Total no. of tubers per plant & $8.62 * *$ & $3.79 * *$ & 121.68 & 0.00 & 41.82 & 1.29 & 16.31 \\
\hline Average tuber weight & $66.41 * *$ & $14.09 * *$ & 27.54 & 0.20 & 13.94 & 18.13 & 27.24 \\
\hline Marketable tuber yield & $1614.60 * *$ & 3.66 & 4539.89 & 2.04 & 1515.20 & 244.40 & 26.71 \\
\hline Total tuber yield & $4128.04 * *$ & 3.18 & 2912.00 & 0.44 & 971.88 & 44.57 & 8.71 \\
\hline
\end{tabular}


Table.3 Mean performance of different genotypes of potato for tuber yield and its components evaluated during 2016-17 and 2017-18

\begin{tabular}{|c|c|c|c|c|c|c|c|c|}
\hline Clones & PH & $\mathrm{BR}$ & GC & LAI & TUB & ATW & MYP & TYP \\
\hline CP 1913 & 22.44 & 3.75 & 34.50 & 5.95 & 5.00 & 12.06 & 49.85 & 47.65 \\
\hline CP 2012 & 19.92 & 3.50 & 41.75 & 6.05 & 9.25 & 13.15 & 33.90 & 51.55 \\
\hline CP 1901 & 20.47 & 3.00 & 46.50 & 5.20 & 8.50 & 13.51 & 55.10 & 122.65 \\
\hline CP 1893 & 29.45 & 2.50 & 38.00 & 5.57 & 5.50 & 22.00 & 58.28 & 108.18 \\
\hline CP 1918 & 26.13 & 2.75 & 29.00 & 4.89 & 6.75 & 16.67 & 52.13 & 83.20 \\
\hline CP 1964 & 19.20 & 2.00 & 29.50 & 4.25 & 5.25 & 16.31 & 39.60 & 40.33 \\
\hline CP 2017 & 31.60 & 2.75 & 47.50 & 3.43 & 5.75 & 11.55 & 32.85 & 65.98 \\
\hline CP 1909 & 26.55 & 2.25 & 44.00 & 4.93 & 8.50 & 14.75 & 47.65 & 47.50 \\
\hline CP 1915 & 28.84 & 2.75 & 51.50 & 3.88 & 6.75 & 14.10 & 66.50 & 78.63 \\
\hline CP 1936 & 21.83 & 1.50 & 23.50 & 3.19 & 3.75 & 17.98 & 42.98 & 45.15 \\
\hline CP 1908 & 24.72 & 2.75 & 46.00 & 5.31 & 7.75 & 13.68 & 73.78 & 71.48 \\
\hline CP 2038 & 19.24 & 1.75 & 30.00 & 7.28 & 7.25 & 10.60 & 46.83 & 47.85 \\
\hline CP 2052 & 26.21 & 2.50 & 31.00 & 4.45 & 7.50 & 14.28 & 44.18 & 59.05 \\
\hline CP 1999 & 21.44 & 2.00 & 31.50 & 7.70 & 5.25 & 14.66 & 30.55 & 20.38 \\
\hline CP 1911 & 28.02 & 2.75 & 40.50 & 6.96 & 7.50 & 15.05 & 55.55 & 72.93 \\
\hline CP 2021 & 27.60 & 2.75 & 26.50 & 6.34 & 8.50 & 13.34 & 79.35 & 97.30 \\
\hline CP 1998 & 28.92 & 2.25 & 40.50 & 5.12 & 7.25 & 10.82 & 73.73 & 78.75 \\
\hline CP 2023 & 21.08 & 2.50 & 26.50 & 10.48 & 7.25 & 16.27 & 72.58 & 81.23 \\
\hline CP 1931 & 20.52 & 2.50 & 44.00 & 11.16 & 9.00 & 16.34 & 28.90 & 71.23 \\
\hline CD (5\%) & 5.81 & 1.14 & 9.19 & 1.72 & 1.59 & 5.97 & 21.91 & 9.35 \\
\hline
\end{tabular}


Int.J.Curr.Microbiol.App.Sci (2020) 9(2): 1974-1983

\begin{tabular}{|c|c|c|c|c|c|c|c|c|}
\hline \multicolumn{9}{|l|}{ Cont..... } \\
\hline Clones & PH & BR & GC & LAI & TUB & ATW & MYP & TYP \\
\hline CP 2010 & 20.09 & 1.75 & 24.50 & 4.60 & 5.00 & 13.19 & 32.75 & 50.80 \\
\hline CP 1962 & 28.56 & 2.75 & 42.00 & 5.75 & 7.00 & 18.07 & 61.45 & 121.15 \\
\hline CP 1902 & 28.85 & 3.25 & 31.50 & 5.83 & 6.75 & 20.11 & 76.60 & 81.53 \\
\hline CP 1994 & 26.41 & 4.25 & 36.00 & 7.44 & 7.25 & 27.52 & 97.05 & 157.55 \\
\hline CP 1997 & 16.32 & 2.00 & 23.00 & 3.63 & 7.75 & 10.11 & 34.90 & 40.80 \\
\hline CP 1987 & 22.75 & 3.00 & 30.50 & 3.52 & 4.00 & 16.46 & 94.65 & 137.95 \\
\hline CP 1982 & 25.13 & 2.25 & 42.50 & 4.61 & 6.25 & 16.31 & 49.70 & 72.20 \\
\hline CP 2048 & 22.81 & 2.75 & 31.50 & 2.22 & 7.00 & 14.14 & 34.50 & 43.35 \\
\hline CP 2016 & 26.89 & 2.00 & 39.50 & 4.53 & 7.50 & 12.44 & 50.35 & 88.70 \\
\hline CP 1916 & 16.03 & 2.00 & 22.50 & 3.92 & 7.50 & 13.54 & 68.55 & 61.10 \\
\hline CP 2008 & 19.81 & 1.75 & 40.50 & 3.75 & 10.25 & 14.92 & 63.98 & 84.30 \\
\hline CP 2015 & 22.73 & 1.75 & 35.50 & 3.51 & 8.25 & 18.99 & 59.03 & 67.73 \\
\hline CP 1981 & 23.76 & 2.00 & 31.00 & 3.17 & 5.00 & 9.91 & 34.70 & 23.08 \\
\hline CP 2045 & 19.06 & 2.25 & 28.00 & 3.41 & 6.75 & 14.27 & 75.00 & 66.10 \\
\hline CP 1914 & 29.40 & 2.25 & 37.50 & 7.78 & 6.50 & 20.18 & 67.15 & 83.73 \\
\hline CP 1924 & 22.18 & 2.75 & 32.50 & 6.51 & 5.75 & 16.49 & 86.05 & 94.98 \\
\hline CP 1986 & 22.69 & 2.25 & 42.50 & 5.46 & 7.00 & 12.95 & 62.45 & 92.85 \\
\hline KufriJyoti (Check) & 30.63 & 2.25 & 44.00 & 5.52 & 8.50 & 19.40 & 94.88 & 107.70 \\
\hline KufriKyati (Check) & 31.82 & 2.50 & 52.50 & 7.32 & 8.75 & 27.91 & 96.55 & 146.98 \\
\hline $\mathrm{CD}(5 \%)$ & 5.81 & 1.14 & 9.19 & 1.72 & 1.59 & 5.97 & 21.91 & 9.35 \\
\hline
\end{tabular}


Table.4.3 Genetic parameters of various characters during 2016-17 and 2017-18

\begin{tabular}{|c|c|c|c|c|c|c|c|c|}
\hline \multirow[t]{2}{*}{ Character } & \multicolumn{2}{|c|}{ Range } & \multirow[t]{2}{*}{ Mean \pm SEm } & \multirow[t]{2}{*}{ GCV (\%) } & \multirow[t]{2}{*}{ PCV (\%) } & \multirow[t]{2}{*}{$\mathrm{h}^{2}{ }_{\mathrm{bs}}(\%)$} & \multirow{2}{*}{$\begin{array}{c}\text { GA }(5 \%), \\
\text { as } \% \text { of } \\
\text { mean }\end{array}$} & \multirow{2}{*}{$\begin{array}{l}\text { Expected } \\
\text { mean next } \\
\text { generation }\end{array}$} \\
\hline & Min & Max & & & & & & \\
\hline $\mathrm{PH}$ & 16.03 & 31.82 & $24.21 \pm 2.07$ & 15.37 & 23.01 & 44.60 & 21.15 & 29.33 \\
\hline $\mathrm{BR}$ & 1.50 & 4.25 & $2.48 \pm 0.41$ & 16.69 & 36.70 & 20.70 & 15.64 & 2.87 \\
\hline GC & 22.50 & 52.50 & $36.05 \pm 3.28$ & 20.65 & 27.52 & 56.30 & 31.92 & 47.55 \\
\hline LAI & 2.22 & 11.16 & $5.38 \pm 0.61$ & 33.89 & 40.83 & 68.90 & 57.97 & 8.51 \\
\hline TUB & 3.75 & 10.25 & $6.97 \pm 0.57$ & 19.41 & 25.35 & 58.60 & 30.61 & 9.11 \\
\hline ATW & 9.91 & 27.91 & $15.63 \pm 2.13$ & 22.23 & 35.16 & 40.00 & 28.94 & 20.16 \\
\hline MYP & 28.90 & 97.05 & $58.54 \pm 7.82$ & 31.62 & 41.39 & 58.40 & 49.76 & 87.67 \\
\hline TYP & 20.38 & 157.55 & $76.67 \pm 3.34$ & 41.67 & 42.57 & 95.80 & 84.03 & 141.10 \\
\hline
\end{tabular}

$\mathrm{GCV}=$ Genotypic coefficient of variation $\mathrm{PCV}=$ Phenotypic coefficient of variation $\mathrm{h}^{2} \mathrm{bs}=$ Broad sense heritability

$\mathrm{GA}=$ Genetic advance

A high heritability was found for total tuber yield per plant and LAI while all other characters except number of branch showed moderate heritability. Number of branch had low heritability. These findings are in accordance with the finding of Fekadu et al., (2013) for plant height and total tuber yield, Asefa et al., (2016) for leaf area index, average tuber weight and marketable tuber yield, Tripura et al., (2016) for number of branches per plant and number of tubers per plant, Nasiruddin et al., (2017) for plant height, leaf area index, number of tubers, Panigrahi and Pradhan (2017) for marketable tuber yield, Mishra et al., (2017) for marketable tuber yield and total tuber yield.

In the present study highest estimates of genetic advance (Table 4) as percentage of mean was obtained for characters namely total tuber yield per plant (84.03). Genetic advance is high for all the characters except branches per plant. Hayder et al., (2009) and Mishra et al., (2006), suggested that high heritability with high genetic advance is indicative of additive gene action and selection based on these parameters would be more reliable. In the studies high heritability with high genetic advance was found for LAI and tuber yield and moderate heritability with moderate genetic advance was found in plant height, ground coverage, number of tubers and average tuber weight which suggested that there may be presence of dominant and epistatic interactions. In agreement to the present results, similar findings were also supported by Ikbal\& Khan (2003) reported high genetic advance for plant height and number of branches per plant, Ahmed et al., (2005) for average tuber weight, number of branches and number of tuber per plant.

\section{References}

Ahmad, I., Hossain, M., Islam, G.M.R., Billah, S.K.M. and Kabir, Y., 2005.Genetic variability and correlation studies in potato (Solanum tuberosum 
L.).Intl. J. Sust. Agri.Tech. 1(4): 30-34.

Asefa, G., Mohammed, W., and Abebe, T. 2016. Genetic variability for yield, related traits and reaction to late blight in potato (Solanum tuberosum L.) genotypes at Sinana, South Eastern Ethiopia, 12(2), 60-64.

Burton, G. W., and E. H. Devane, 1953. Estimating heritability in tall fesque (Festucu arundinacea) from replicated clonal material. Agron. J. 45: 478-481.

Chaudhary, S. K. and Sharma, S. K. 1984. Genetic variability for yield and its components in potato breeding material. Indian J. Agric. Sci. 54(10):941-2.

Dayal, T. R., Upadhyay, M.D., Malhotra, V.P. and Mehra, K. L., 1972. Heritability and correlation in yield and other quantitative characters in potato (Solanum tuberosum L.). Indian $J$. Agric. Sci. 42(6): 464-466.

Dixit, D.; Mittal, R.K.; Choubey, C.N. and Singh, P. 1994. Variability, correlations and selection indices in potato (Solanum tuberosum L.). Haryana J. Hort. Sci. 23(2):168-172.

Fekadu, A., Petros, Y., and Zelleke, H. 2013. Genetic variability and association between agronomic characters in some potato (Solanum tuberosum L.) genotypes in SNNPRS, Ethiopia. International Journal, 5(8), 523-528.

Gopal, J. 1999. Genetic parameters and character association for clonal selection in potato breeding programmes: HAL Id: hal-00885951 Genetic parameters and character association.

Grag, K.C. 1988. A study of dihaploids derived from five Indian cultivars of potato. Haryana J. Hort. Sci. 20: 255260.

Haydar, A., Alam, M.K., Khokan, E.H., Ara, T., and Khalequzzaman, K.M. 2009. Combining ability and genetic variability studies in potato. J. Soil.
Nature. 3(2): 01-03.

Iqbal, M. Z., and Khan, S. A. 2003. Genetic variability, partial regression, coheritability studies and their implication in selection of high yielding potato genotypes. Pakistan Journal of Scientific and Industrial Research, 46(2).

Johnson, H.W., Robinson, H.F. and Comstock, R.E. 1955. Estimation of genetic and environmental variability in soybean. Agron. J. 47: 477-483.

Joseph, T.A., Gopal, J., Sood. S.K. 2005. Genetic parameters and character associations in potato under sub-tropical plains and temperate hill conditions. Potato J. 32 (1-2): 49-53.

Kanica, R.A. 2010. Genetic variability and character association in potato (Solanum tuberosum L.). M.S. thesis, Dept. of Genetics and Plant Breeding. Bangladesh Sheikh Mujibur Rahman University, Gazipur.

Khan, S.H., Hussain, K., Jabeen, N., Chattoo, M.A., Afroza, B. and Mushtaq, F. 2011. Agrobiodiversity of potato (Solanum tuberosum L.) in Kashmir valley, Asian J. Hort., 6 (2) : 275-278.

Kumar, V., Gopal, J. and Bhardwaj, V. 2005. Evaluation of exotic potato (Solanum tuberosum L. spp. Tuberosum) germplasm in North - Western Hills of India. Indian J. Plant Genetic Resources. Vol. 18, No. 1: 94-95.

Luthra, S. K., Gopal, J. and P. C. 2005. Genetic divergence and its relationship with heterosis in potato. Potato J. 32 (12):37-42.

Mishra, S., Singh, J., and Sharma, P. K. 2017. Studies on Parameters of Genetic Variability for Yield and its Attributing Traits in Potato (Solanum tuberosum L.), 14(March), 489-495.

Mishra, A. C., Singh, N. P., Kamal, S., and Kumar, V. 2006. Studies on genetic variability, heritability and genetic 
advance in Potato (Solanum tuberosum L.). International Journal of Plant Sciences, 1(1), 39-41.

Nasiruddin M., Haydar F. A., Islam R., 2017. Genetic diversity in potato (Solanum tuberosum L.) genotypes grown in Bangladesh. International Research Journal of Biological Sciences. Vol. 6(11), 1-8.

Panigrahi, K. K., and Pradhan, J. 2017. Genetic Variability, Character Association and Path Coefficient Analysis of Yield Attributes for Medium and Late Maturing Potato Cultivars, 6(7), 2558-2566.

Rana, M.S., Sharma B.D., Kang, G.S., Singh, A.N., Gaur, P.C. and Pandey, S.K. 1996. Kufri Sutlej, a new medium maturing potato variety for western and central Indo-Gangetic plains of India. $J$. Indian Potato Assoc. 23(3-4):108-111.

Rasul, M.G., Islam, M.A., Nahar, M.S. and Rashid, M.M. 1995. Heritability, variability and correlation in the first clonal generation of tuberlets progenies derived from true potato seed. Bangladesh J. Scientific and Industrial
Res. 30(2/3):161-170.

Robinson, H.F., Comstock, R.E. and Harvey, V.H. 1949. Estimates of heritability and degree of dominance in corn. Agron. J. 41: 353-359.

Roy, S. K. and Sharma, R.C. 2000. Effect of nitrogen, phosphorus and time schedules of haulm cutting on production of small sized (up to $40 \mathrm{~g}$ ) tuber in seed potato (Solanum tuberosum L.) Crop Indian J. Agric. Sci. 70 (7):441-445.

Tripura, A., Das, A., Das, B., Priya, B., and Sarkar, K. K. 2016. Genetic studies of variability, character association and path analysis of yield and its component traits in potato (Solanum tuberosum L..), 12(1), 56-63.

Visser, R. G. F., Bachem, C. W. B., de Boer, J. M., Bryan, G. J., Chakrabati, S. K., Feingold, S., Tang, X. 2009. Sequencing the Potato genome: Outline and first results to come from the Elucidation of the sequence of the world's third most important food crop. American Journal of Potato Research, 86(6), 417-429.

\section{How to cite this article:}

Lopamudra Singha and Zafar Ullah. 2020. Genetic Variability Studies for Yield and it's Attributing Traits in Potato (Solanum tuberosum L.). Int.J.Curr.Microbiol.App.Sci. 9(02): 1974-1983. doi: https://doi.org/10.20546/ijcmas.2020.902.225 